\title{
Phosphate Modified Copper Electrodes for Methanol Fuel Cell
}

\author{
Sanae Dehbi, ${ }^{1}$ Harouna Massai, ${ }^{1,2}$ Abdelilah Chtaini ${ }^{1, *}$ \\ ${ }^{1}$ Equipe d'Electrochimie Moléculaire et Matériaux Inorganiques, \\ Faculté des Sciences et Techniques de Beni Mellal, Maroc \\ ${ }^{2}$ Laboratoire de Chimie Physique et Théorique, Université Yaoundé I, \\ Faculté des Sciences, Cameroun
}

Received 16 March 2010; accepted 28 July 2010

\begin{abstract}
This work aims to investigate the electro oxidation of methanol, in alkaline solution at a copper electrode modified with electrodeposited natural phosphate and nickel (Ni$\mathrm{NP} / \mathrm{Cu}$ ), by cyclic voltammetry, impedance measurements and square wave voltammetry. Morphological characterizations were performed by SEM and XRD techniques. It was found that $\mathrm{Ni}$ dispersed on natural phosphate (NP) shows a catalytic activity towards methanol oxidation better than massive Ni. Ni and NP were fixed on copper electrode by electro deposition using potentiostatic and galvanostatic techniques.
\end{abstract}

Keywords: methanol fuel cell; electro catalysis; modified electrodes; nickel catalyst; square wave voltammetry.

\section{Introduction}

Fuel cells are efficient and environmentally acceptable conversion devices. Electric current is generated in the fuel cell by the direct electrochemical oxidation of either hydrogen (proton exchange membrane fuel cell, PEM) or methanol (Direct Methanol Fuel Cell, DMFC). The electrochemical processes that yield energy are essentially pollution free. Water formed during the operation of the device is beneficial in space travel and submarines. Applications of fuel cells are diverse ranging from stationary (individual homes or district schemes) or mobile (transportation as cars, buses, etc.), mobile phones and lap top computers $[1,2]$.

\footnotetext{
* Corresponding author. E-mail address: chtainia@yahoo.fr
} 
Hydrogen is currently the only practical fuel for use in the present generation of fuel cells. The main reason for this is its high electrochemical reactivity compared with that of the more common fuels from which it is derived, such as hydrocarbons, alcohols, or coal.

Also, its reaction mechanisms are now rather well understood [3, 4] and are characterized by the relative simplicity of its reaction steps, which lead to no side products.

Pure hydrogen is attractive as a fuel, because of its high theoretical energy density, its innocuous combustion product (water), and its unlimited availability so long as a suitable source of energy is available to decompose water. One of the disadvantages of pure hydrogen is that it is a low density gas under normal conditions, so that storage is difficult and requires considerable excess weight compared with liquid fuels.

Methanol has been considered for fuel cell power generation for a number of years because it can be processed into a hydrogen-rich fuel gas fairly, easily and efficiently, by steam or auto thermal reforming. Methanol, as a liquid fuel is easily transported and stored in comparison to hydrogen gas.

The methanol fuel has a superior specific energy density $(6000 \mathrm{Wh} / \mathrm{kg})$ in comparison with the best rechargeable battery, lithium polymer and lithium ion polymer $(600 \mathrm{Wh} / \mathrm{kg})$ systems. This means longer conservation times using mobile phones, longer times for use of laptop computers and more power available on these devices to support consumer demand. Another significant advantage of the direct methanol fuel cells over the rechargeable battery is their potential for instantaneous refuelling [5-7].

The methanol fuel cells in alkaline solutions have many advantages such as increasing their efficiency, a wider selection of possible electrode materials, a better efficiency of oxygen cathode, and the oxidation reactions of organic fuels exhibit almost no sensitivity to the surface structure $[8,9]$.

Moreover, the use of the methanol fuel cells is limited by the poor anode performance and counteract the poisoning effects at the cathode due to the methanol cross-over $[10,11]$.

In the electro oxidation of methanol, the electrode material is clearly an important parameter where a high efficient electro catalyst is needed.

The use of Pt alone is limited by the adsorption of several incompletely oxidized intermediates $[13,14]$ which provoke deactivation of platinum surface. For this reason, there are several studies investigating modified $\mathrm{Pt}$, for methanol electro oxidation, such, Pt-Ru [15], Pt-Pb [16], Pt-Ni and Pt-Ru-Ni [17].

Several studies of the alcohols electro oxidation on $\mathrm{Ni}$ have been investigated $[18,19]$ due to its surface oxidation properties.

The purpose of the present work is to establish the electro oxidation of methanol on copper electrode-modified with natural phosphate and nickel in alkaline solution. 


\section{Experimental part \\ Electrodes}

Electrochemical measurements were performed on copper plate electrode of apparent surface area of $1 \mathrm{~cm}^{2}$ modified by natural phosphate and nickel. The copper electrode was mechanically polished using smooth paper, and then it was subsequently degreased with acetone and rinsed with distilled water. Before each experiment, the electrode surface was activated via the cyclic voltammetry at scan rate of $500 \mathrm{mV} / \mathrm{s}$ for 20 cycles.

The working electrodes $(\mathrm{Ni}-\mathrm{NP} / \mathrm{Cu}, \mathrm{Ni}, \mathrm{NP} / \mathrm{Cu}$ and $\mathrm{Cu}$ ) were sealed in Teflon jacket. The apparent surface area was calculated from geometrical area and the current density was referred to it.

\section{Reagents}

A natural phosphate (NP) used in this work was obtained in the Khouribga region (Morocco) [20]. Prior to use, this material was treated by techniques involving attrition, sifting, calcinations $\left(900{ }^{\circ} \mathrm{C}\right)$, washing, and recalcination [21]. Measurements were carried out in aerated $1 \mathrm{M} \mathrm{KOH}$ at room temperature $(20 \pm$ $\left.0.2^{\circ} \mathrm{C}\right)$.

\section{Instrument}

Cyclic voltammetry, chronoamperommetry, chronopotentiommetry, impedance (EIS), polarization curves and square wave voltammetry were carried out with a Voltalab potentiostat (Model PGSTAT 100, Ecochemie B.V., Utrecht, the Netherlands) driven by the general purpose electrochemical systems data processing software (Voltalab Master 4 software). The electrochemical cell was configured to work with three electrodes using (Ni massive (plate), copper (plate), NP-Cu (plate) and Ni-NP-Cu (plate)) as the working electrodes, platinum plate $\left(1 \mathrm{~cm}^{2}\right)$ for counter electrode and $\mathrm{Ag}-\mathrm{AgCl}$ as reference electrode.
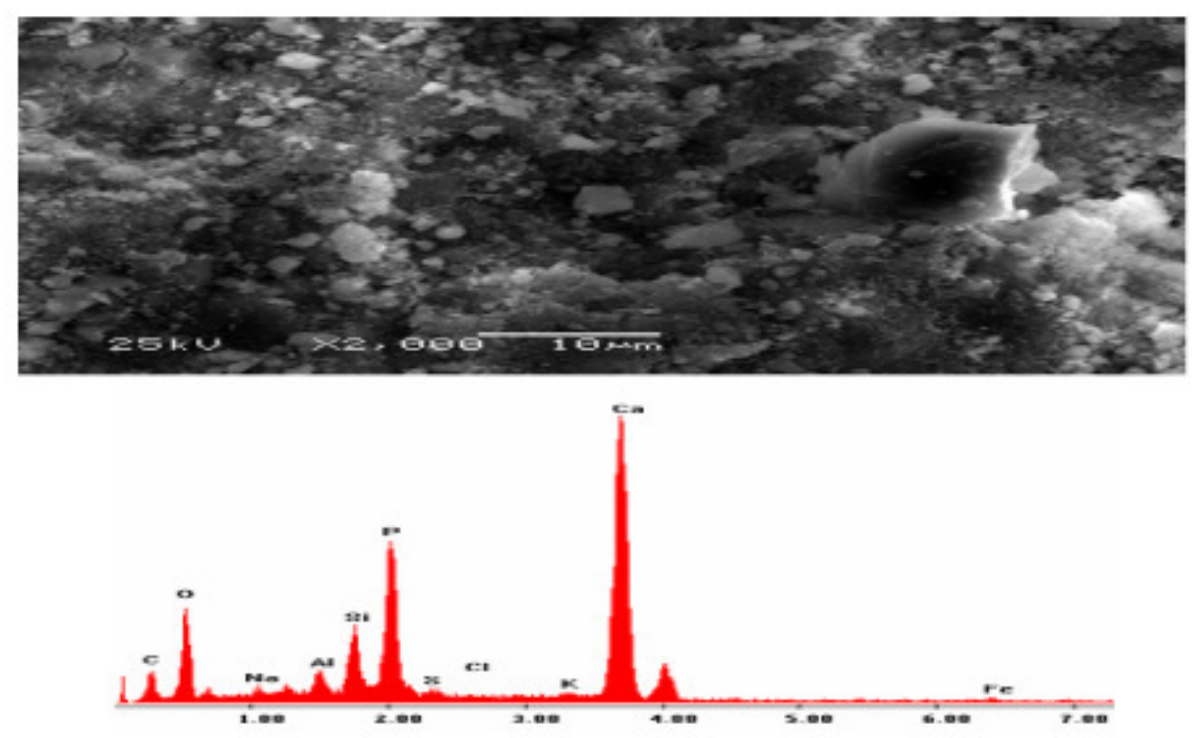

Figure 1. Scanning electron micrograph of natural phosphate. 


\section{Results and discussion}

\section{Natural phosphate characteristics}

The surface structure of natural phosphate (NP) was observed using scanning electron microscopy (Fig. 1). The treatment of NP described above leads to a fraction between $100 \mu \mathrm{m}$ and $400 \mu \mathrm{m}$ that is rich in phosphate and, as can be seen, that compact natural phosphate appearance was evident. The treated NP has following chemical composition:

$\mathrm{CaO}(54.12 \%), \mathrm{P}_{2} \mathrm{O}_{5}(34.24 \%), \mathrm{F}^{-}(3.37 \%), \mathrm{SiO}_{2}(2.42 \%), \mathrm{SO}_{3}(2.21 \%), \mathrm{CO}_{2}$ $(1.13 \%), \mathrm{Na}_{2} \mathrm{O}(0.92 \%), \mathrm{MgO}(0.68 \%), \mathrm{Fe}_{2} \mathrm{O}_{3}(0.36 \%), \mathrm{K}_{2} \mathrm{O}(0.04 \%)$ and several metals in the range of ppm.

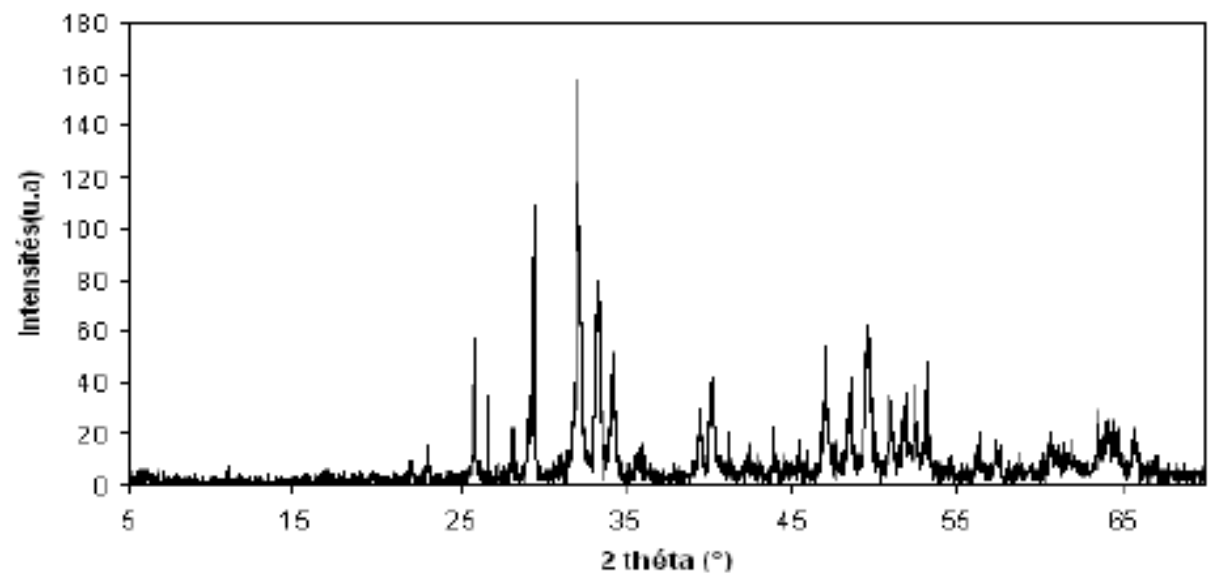

Figure 2. XRD pattern of the natural phosphate.

The crystal-structure of matter is similar to that of fluorapatite (Ca10 (PO4) 6F2), as shown by X-ray diffraction (Fig. 2) and infrared emission spectroscopy (Fig. 3 ). The network of fluorapatite is very tolerant to substitutions in vacant sites, such as $\mathrm{Ca}$ can be replaced by $\mathrm{Sr}, \mathrm{Pb}, \mathrm{Co}$ and $\mathrm{Na}, \mathrm{PO}_{4}$ by $\mathrm{AsO}_{4}, \mathrm{VO}_{4}$ and $\mathrm{SO}_{4}$, and $\mathrm{F}^{-}$can be replaced by $\mathrm{OH}^{-}$and $\mathrm{Cl}^{-}$. The phosphate has a low specific surface area of about $1 \mathrm{~m}^{2} \mathrm{~g}^{-1}$.

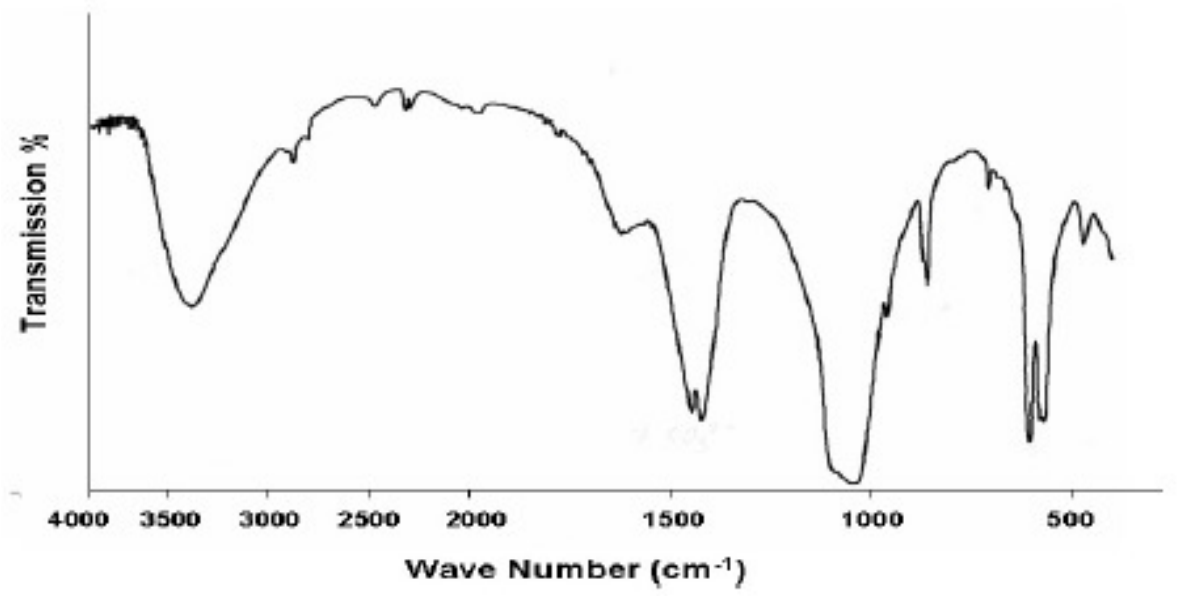

Figure 3. IR spectrum of the natural phosphate. 


\section{Characterization of prepared electrodes}

Fig. 4 shows the polarization curves recorded for copper, NP-Cu and $\mathrm{Ni}-\mathrm{NP}-\mathrm{Cu}$ electrodes, respectively, in $1 \mathrm{M} \mathrm{KOH}$ solution.

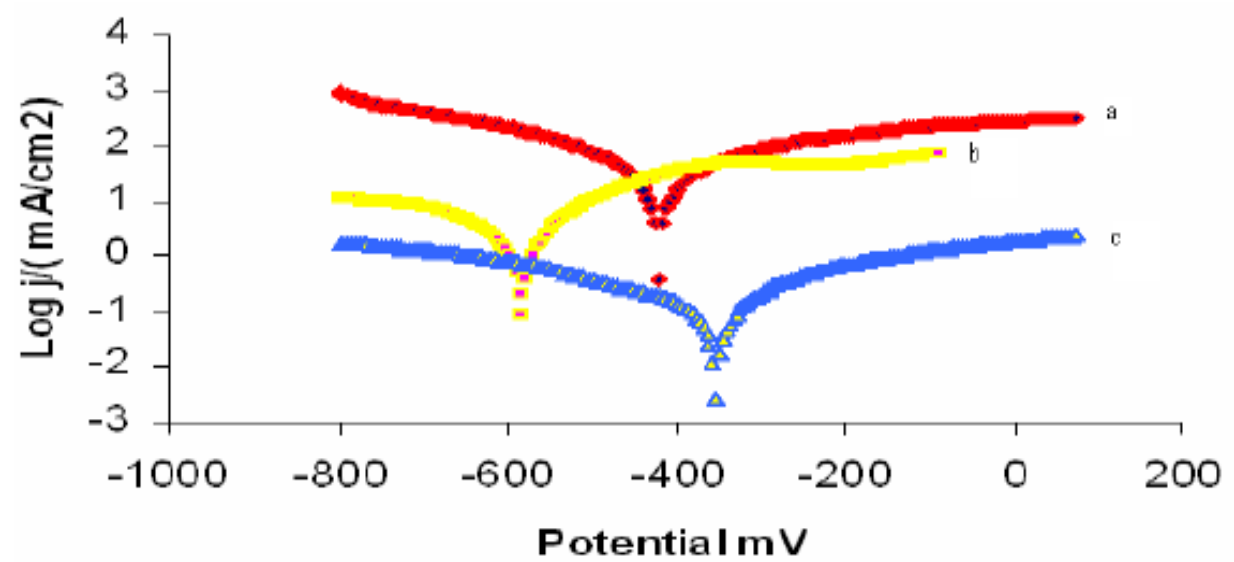

Figure 4. Polarization curves for copper (a), NP-Cu (b) and Ni-NP-Cu (c) electrodes in $1 \mathrm{M} \mathrm{KOH}$ solution.

The cathodic current potential curves give rise to parallel Tafel lines, indicating that the hydrogen evolution reaction is activation controlled and the presence of the electrodeposited NP and Ni products, does not modify the mechanism of this reaction. In the anodic domain, the addition of these products decreases the current densities in large domain of potential; this decrease is very important in the simultaneous presence of $\mathrm{NP}$ and $\mathrm{Ni}$, in anodic and cathodic region. The collected parameters deduced from the polarization curves, such as the corrosion potential $\left(\mathrm{E}_{\mathrm{corr}}\right)$, corrosion current density $\left(\mathrm{j}_{\mathrm{corr}}\right)$, cathodic and anodic Tafel slopes $\left(\beta_{\mathrm{c}}\right.$ and $\left.\beta_{\mathrm{a}}\right)$, are shown in Table 1 .

Table 1. Electrochemical parameters.

\begin{tabular}{cccccc}
\hline Samples & $\mathbf{E}(\mathbf{j}=\mathbf{0}) / \mathbf{m V}$ & $\mathbf{R p}\left(\mathbf{m o h m} . \mathbf{c m}^{2}\right)$ & $\mathbf{j c o r r}\left(\mathbf{m A} / \mathbf{c m}^{2}\right)$ & $\mathbf{B}_{\mathbf{a}}(\mathbf{m V})$ & $\mathbf{B}_{\mathbf{c}}(\mathbf{m V})$ \\
\hline $\mathrm{Cu}$ & -419.4 & 1.25 & 115.35 & 1081 & -498 \\
$\mathrm{NP}-\mathrm{Cu}$ & -581.5 & 127.7 & 6.6904 & 481.3 & -1006.2 \\
$\mathrm{Ni}-\mathrm{NP}-\mathrm{Cu}$ & -352.2 & 198.3 & 0.477 & 589.6 & -786 \\
\hline
\end{tabular}

The results of the potentiodynamic polarization experiments were confirmed by impedance measurements, from electrochemical impedance spectroscopy (EIS). The Nyquist plots for the tested electrodes $(\mathrm{Cu}, \mathrm{NP}-\mathrm{Cu}$ and $\mathrm{Ni}-\mathrm{NP}-\mathrm{Cu})$ in alkaline solution are presented in Fig. 5.

The locus of Nyquist plots is regarded as one part of semi circle in copper electrode, but in presence of NP and Ni the plots are not perfect semi circles. This feature had been attributed to frequency dispersion of interfacial impedance. 


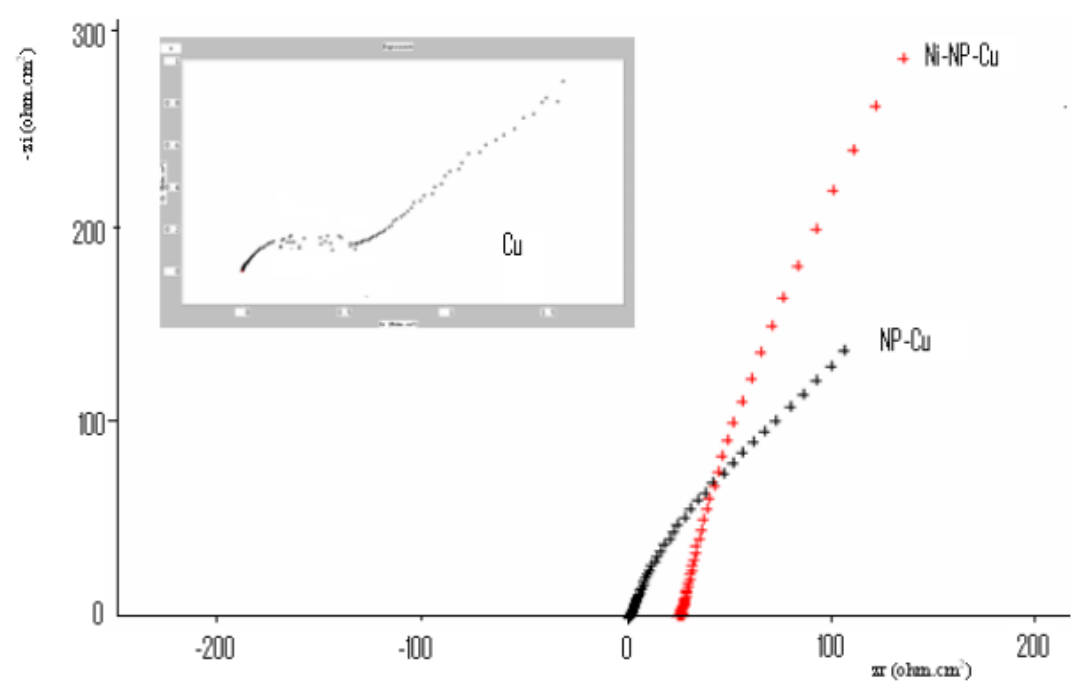

Figure 5. Electrochemical impedance spectroscopy for $\mathrm{Cu}, \mathrm{NP}-\mathrm{Cu}$ and $\mathrm{Ni}-\mathrm{NP}-\mathrm{Cu}$ electrodes, in $1 \mathrm{M} \mathrm{KOH}$ solution.

\section{Methanol oxidation}

The cyclic voltammetric behaviour of massive nickel electrode in $\mathrm{N}_{2}$-saturated 1 $\mathrm{M} \mathrm{KOH}$ solution is shown in Fig. 6. Polarization was started by potential scanning at scan rate of $100 \mathrm{mV} / \mathrm{s}$ from -1200 to $1000 \mathrm{mV}$ in the anodic direction, and then the scan was reversed in the cathodic direction back to -1200 $\mathrm{mV}$.

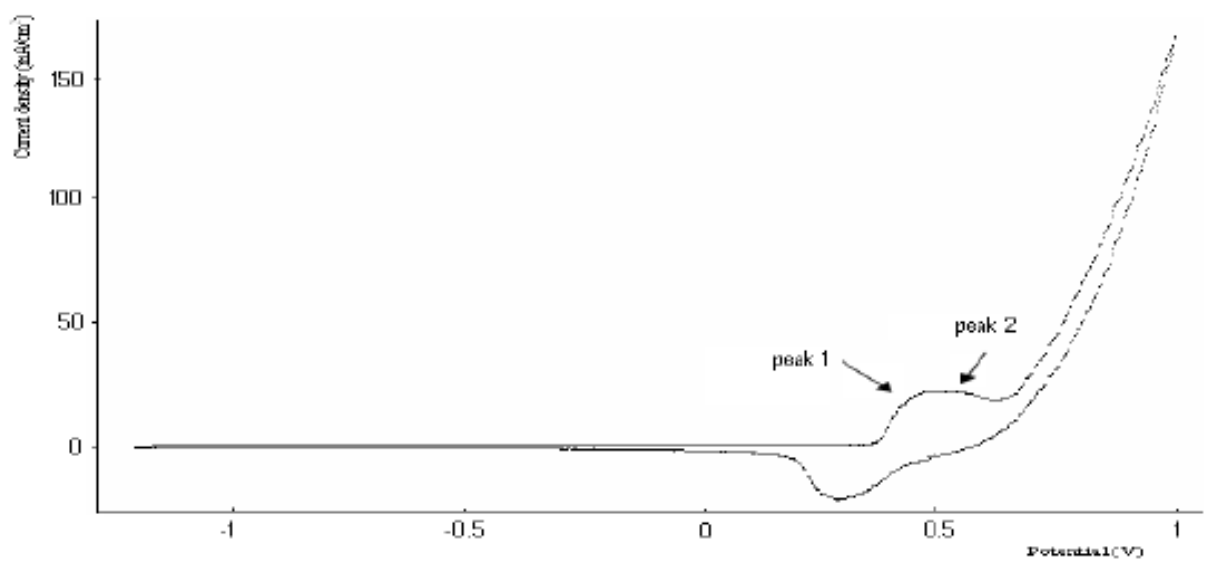

Figure 6. Cyclic voltammetry in $\mathrm{N}_{2}$ - saturated $1 \mathrm{M} \mathrm{KOH}$ recorded for massive nickel electrode. Scan rate $100 \mathrm{mV} / \mathrm{s}$.

In the anodic direction two peaks can be observed between the potential values 0.34 and $0.6 \mathrm{~V}$; the first one corresponds to the oxidation of nickel according to the reaction $[22,23,9]$

$$
\mathrm{Ni}+2 \mathrm{OH}^{-} \leftrightarrows \mathrm{Ni}(\mathrm{OH})_{2}+2 \mathrm{e}^{-}
$$

The second peak can be attributed to the oxidation of $\mathrm{Ni}(\mathrm{OH})_{2}$ according to the reaction [24] 


$$
\mathrm{Ni}(\mathrm{OH})_{2}+\mathrm{OH}^{-} \leftrightarrows \mathrm{NiOOH}+\mathrm{e}^{-}
$$

In the cathodic direction one peak is observed at $0.3 \mathrm{~V}$, corresponding to the reduction of $\mathrm{NiOOH}[25]$.

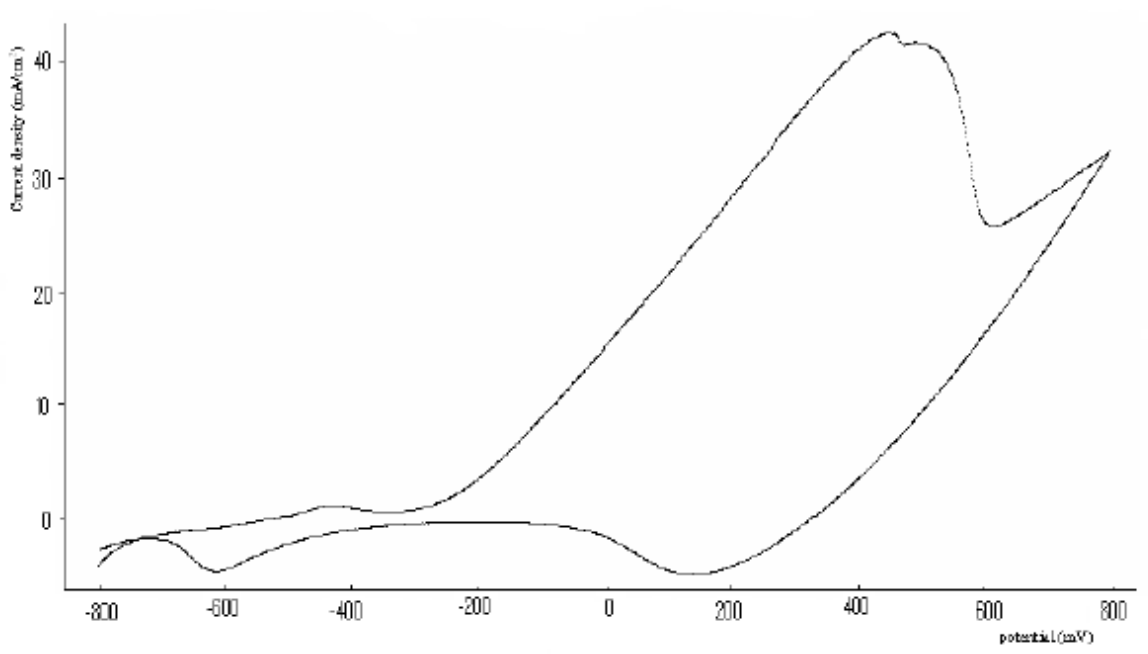

Figure 7. Cyclic voltammetry in $\mathrm{N}_{2}$ - saturated $1 \mathrm{M} \mathrm{KOH}$ recorded for $(\mathrm{Ni}-\mathrm{NP}) / \mathrm{Cu}$ electrode. Scan rate $50 \mathrm{mV} / \mathrm{s}$.

Fig. 7 shows the cyclic voltammograms enregistred in $\mathrm{N}_{2^{-}}$saturated $1 \mathrm{M} \mathrm{KOH}$ solution for (Ni-NP)/Cu electrode, at scan rate $50 \mathrm{mV} / \mathrm{s}$ from -800 to $800 \mathrm{mV}$. The voltammogram shows the existence of two anodic peaks between the potential values 0.4 and $0.5 \mathrm{~V}$ corresponding, respectively, to reaction (1) and (2).

In the cathodic direction we can observe two cathodic peaks, the big one corresponding to the reversible $\mathrm{Ni}(\mathrm{OH})_{2} / \mathrm{NiOOH}$ transformation, and the smaller can be attributed to the reduction of various species present in natural phosphate matrix.

Fig. 8 shows a typical example of cyclic voltammograms for massive nickel electrode measured in $\mathrm{N}_{2}$-saturated $1 \mathrm{M} \mathrm{KOH}$ solution containing $1 \mathrm{M}$ methanol. These experiments show that massive nickel is not an efficient catalyst for the electro-oxidation of methanol.

However, the prepared (Ni-NP)/Cu electrode shows a good catalytic activity (Fig. 9).

Before the electro deposition of nickel on support, the cyclic voltammogram behaviour of NP/Cu electrode was examined.

Fig. 10 shows the cyclic voltammograms recorded for $\mathrm{NP} / \mathrm{Cu}$ electrode in $1 \mathrm{M}$ $\mathrm{KOH}$ solution in the presence or in the absence of methanol. This figure shows that $\mathrm{NP} / \mathrm{Cu}$ electrode is not electro-active for methanol oxidation. After the electro-deposition of $\mathrm{Ni}$ on the $\mathrm{NP} / \mathrm{Cu}$ support, the voltammogram enregistred in $1 \mathrm{M} \mathrm{KOH}$ solution (Fig. 11) shows the existence of two anodic peaks at potential values of about 100 and $400 \mathrm{mV}$. The first one can be attributed to the oxidation of nickel, and the second one, associated to the cathodic peak, corresponds to reversible $\mathrm{Ni}(\mathrm{OH})_{2} / \mathrm{NiOOH}$ transformation. 
Addition of methanol to $1 \mathrm{M} \mathrm{KOH}$ solution provokes change on the $(\mathrm{Ni}-\mathrm{NP}) / \mathrm{Cu}$ voltammogram (Fig. 12). This figure shows that the electro-oxidation of methanol causes a significant shift of the potential of the cathodic peak. It was suggested that methanol is oxidized on the nickel through the reaction with $\mathrm{NiOOH}$ to form $\mathrm{Ni}(\mathrm{OH})_{2}[26]$.

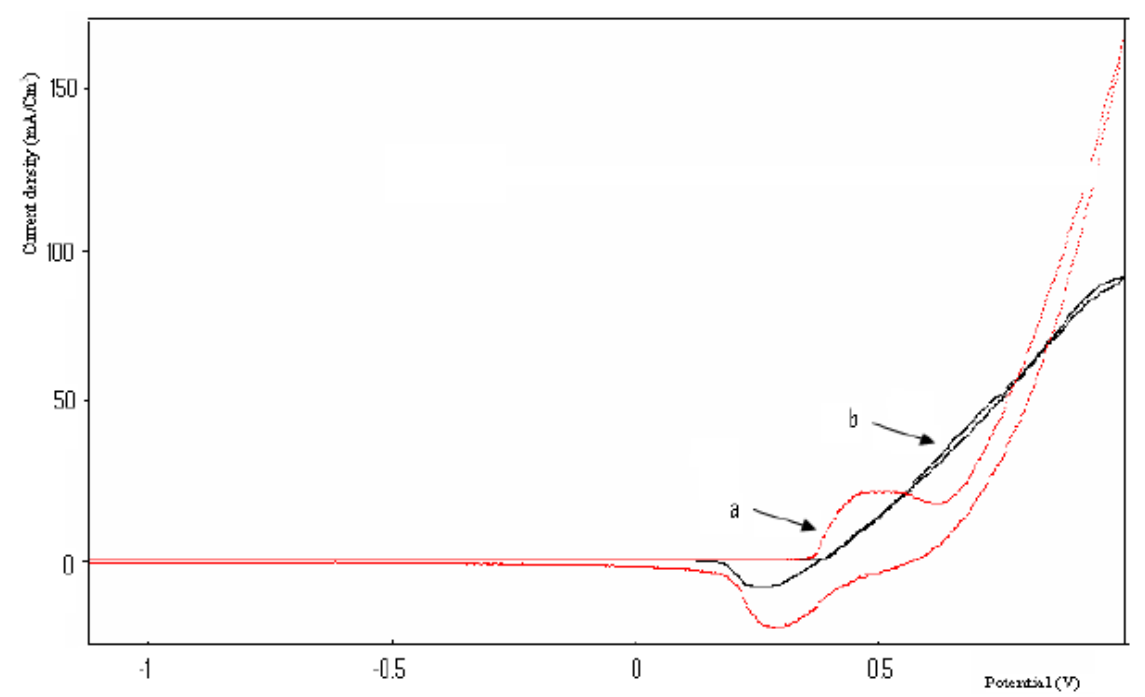

Figure 8. Cyclic voltammetry in $\mathrm{N}_{2}$ - saturated $1 \mathrm{M} \mathrm{KOH}$, a- without methanol, b- with methanol $(1 \mathrm{M})$, recorded for massive Ni electrode. Scan rate $50 \mathrm{mV} / \mathrm{s}$.

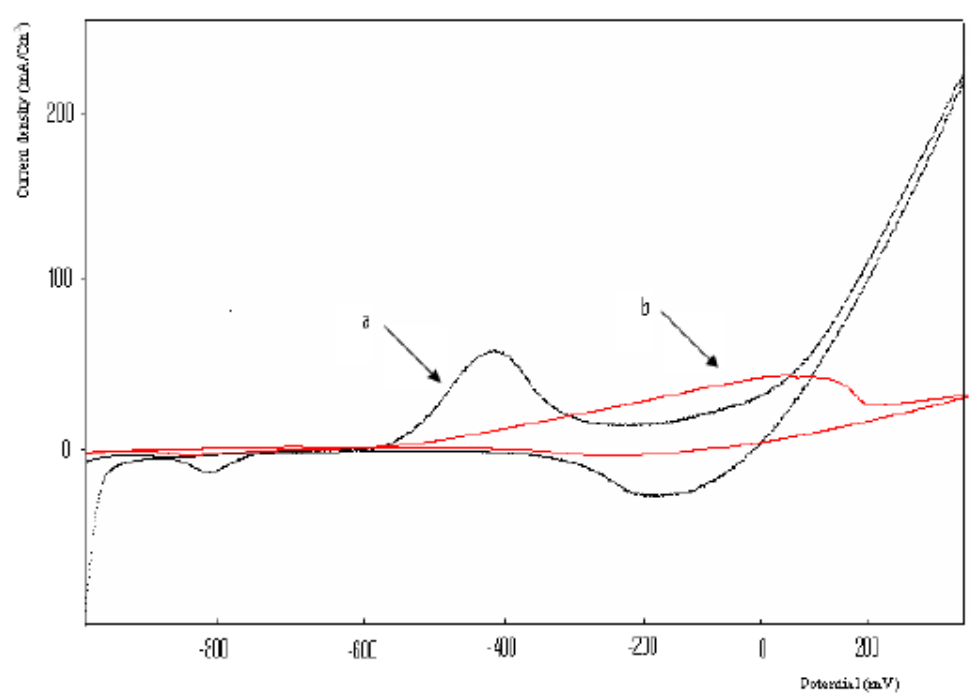

Figure 9. Cyclic voltammetry in $\mathrm{N}_{2}$ - saturated $1 \mathrm{M} \mathrm{KOH}$, a- with methanol (1 M), bwithout methanol, recorded for $(\mathrm{Ni}-\mathrm{NP}) / \mathrm{Cu}$ electrode. Scan rate $50 \mathrm{mV} / \mathrm{s}$.

Fig. 12 shows the cyclic voltammograms recorded for (Ni-NP)/Cu electrode in 1 $\mathrm{M} \mathrm{KOH}$ solution containing various concentrations of methanol. The current density increases with increasing methanol concentration.

Fig. 13 represents the square wave voltammograms enregistred for $(\mathrm{Ni}-\mathrm{NP}) / \mathrm{Cu}$ electrode in $1 \mathrm{M} \mathrm{KOH}$ solution containing various concentrations of methanol. The figure shows the existence of two peaks. The first one, at potential value about $-200 \mathrm{mV}$, and the second one, which increases with increasing methanol 
concentration, at about $600 \mathrm{mV}$ : it was suggested that this peak corresponds to methanol oxidation.

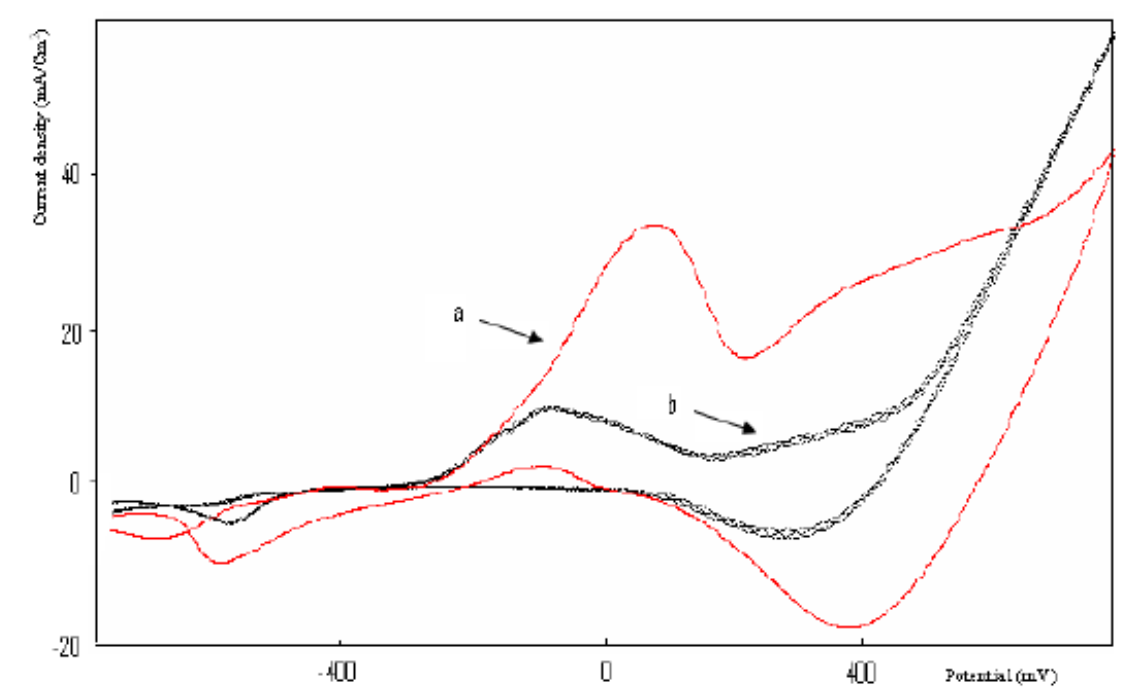

Figure 10. Cyclic voltammetry in $\mathrm{N}_{2}$ - saturated $1 \mathrm{M} \mathrm{KOH}$, a- without methanol, b- with methanol $(1 \mathrm{M})$, recorded for NP/Cu electrode. Scan rate $50 \mathrm{mV} / \mathrm{s}$.

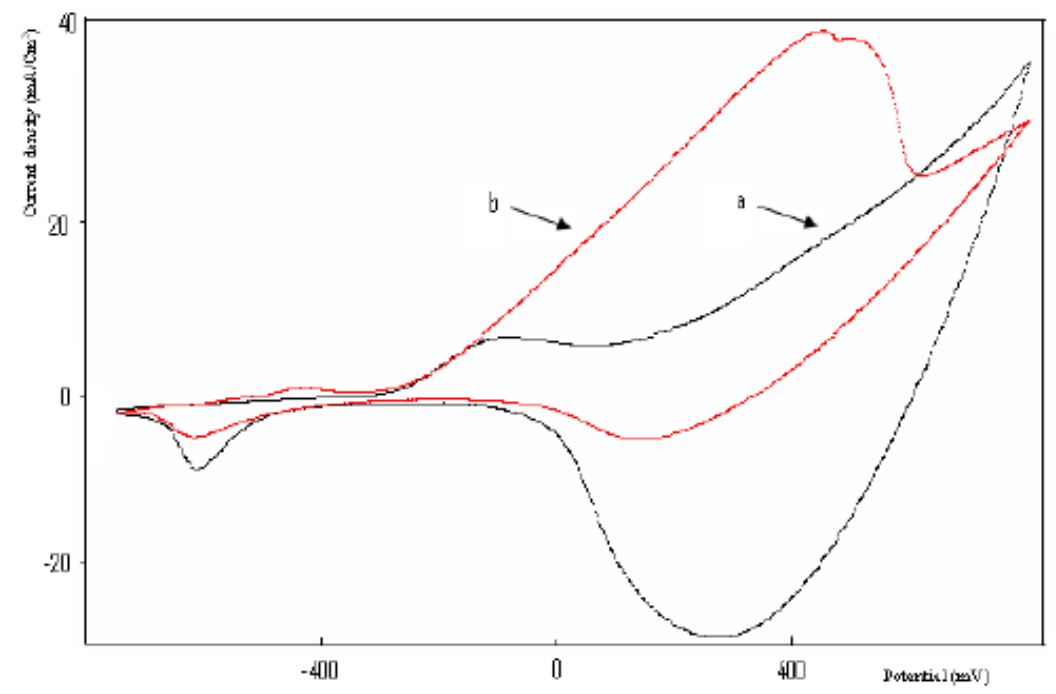

Figure 11. Cyclic voltammetry in $\mathrm{N}_{2}$ - saturated $1 \mathrm{M} \mathrm{KOH}$, recorded for, a-NP/Cu and b- $(\mathrm{Ni}-\mathrm{NP}) / \mathrm{Cu}$ electrodes. Scan rate $50 \mathrm{mV} / \mathrm{s}$.

The methanol concentration effect was investigated. The calibration graph was then constructed from the methanol oxidation peak currents (Fig. 14). The linear regression analysis gave:

$$
\log \mathrm{j}_{\mathrm{p}}=0.4728[\text { methanol }]+1.284
$$

where $\mathrm{j}_{\mathrm{p}}$ is the peak current density. 


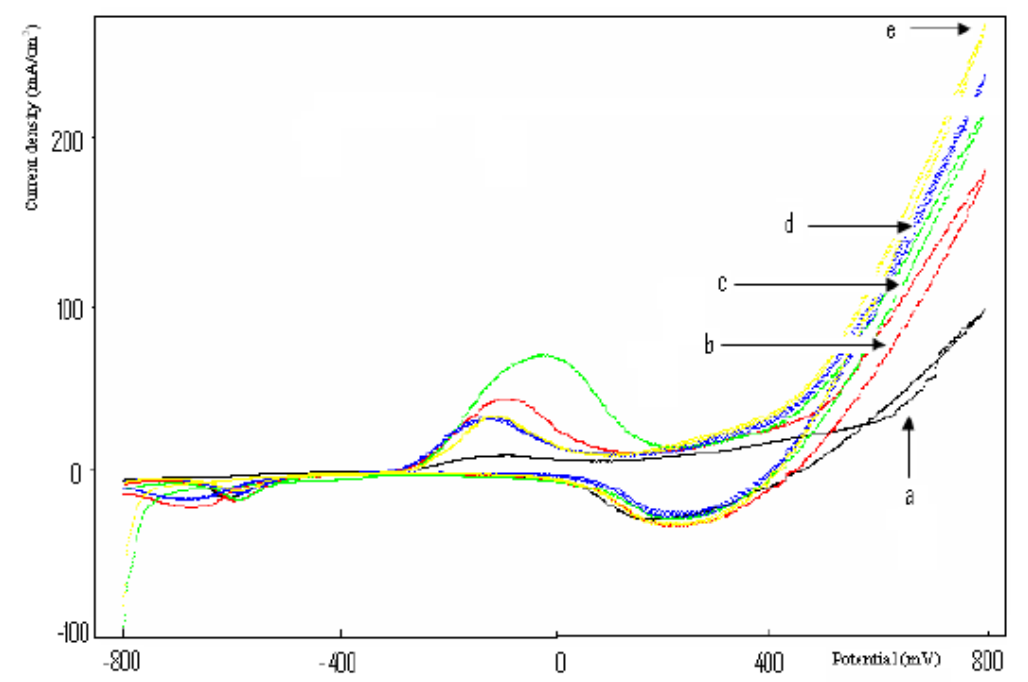

Figure 12. Cyclic voltammetry in $\mathrm{N}_{2^{-}}$saturated $1 \mathrm{M} \mathrm{KOH}$, recorded for $(\mathrm{Ni}-\mathrm{NP}) / \mathrm{Cu}$ electrode in presence of various concentration of methanol, a- $0.1 \mathrm{M}, \mathrm{b}-0.2 \mathrm{M}$, c- 0.6 M, d- $0.8 \mathrm{M}$ and e- $1 \mathrm{M}$. Scan rate $50 \mathrm{mV} / \mathrm{s}$.

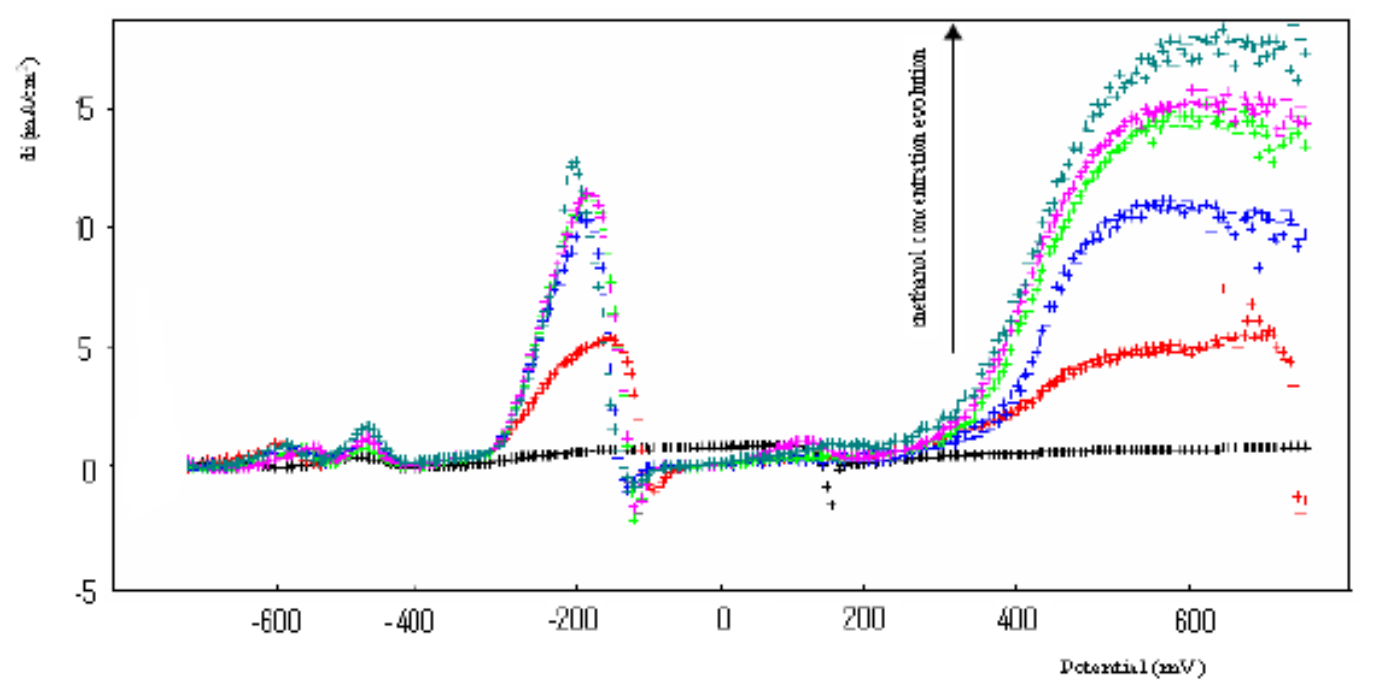

Figure 13. Square wave voltammetry in $\mathrm{N}_{2}$ saturated $1 \mathrm{M} \mathrm{KOH}$, recorded for (Ni$\mathrm{NP}) / \mathrm{Cu}$ electrode in presence of various concentrations of methanol.

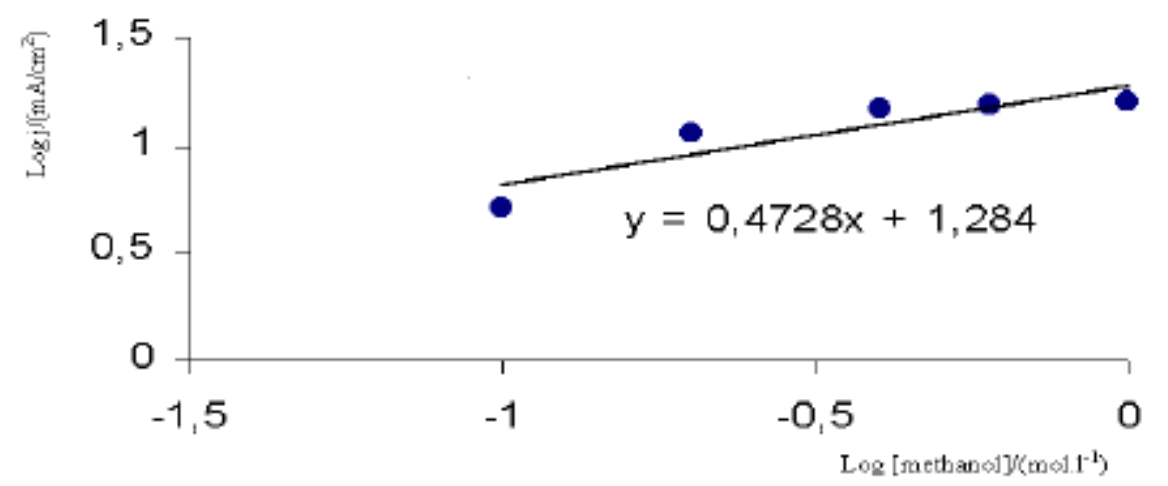

Figure 14. Calibration curve of methanol oxidation at (Ni-NP)/Cu electrode in alkaline solution. 


\section{Conclusion}

The current study introduces a novel anode for the electro-catalytic oxidation of methanol in alkaline medium. The $(\mathrm{Ni}-\mathrm{NP}) / \mathrm{Cu}$ anodes prepared by the potentiostatic deposition of natural phosphate and nickel, respectively, on copper surface, are good catalysts for methanol electro-oxidation.

The methanol oxidation peak increases with increasing the alcohol concentration.

\section{References}

1. P.J. Neel, MVC Sastry Hall, NCCR, $16^{\text {th }}$ February 2008.

2. A.C. Sania, Carabineiro and David T. Thompson, Catalytic Applications of Gold Nanotechnology in Nanoscience and Technology, Nanocatalysis, U. Heiz, U. Landman (Eds). Springer-verlag, Berlin Heidelberg, 2007, p. 463.

3. A.J. Appleby and F.R. Foulkes, Fuel Cell Handbook, Van Nostrand Reinhold, New York.

4. A. Chtaini, Thesis, Poitiers (Frensh), 1993.

5. V. Baglio, A. Di Blasi, E. Modica, P. Creti, V. Antonucci, A.S. Arico, Int. J. Electrochem. Sci. 1 (2006) 71.

6. R. Dillon, S. Srinivasan, A.S. Arico, V. Antonucci, J. Power Sources 127 (2004) 112. [10.1016/j.jpowsour.2003.09.032]

7. X. Ren P. Zelenay, S. Thomas, J. Davey, S. Gottesfeld, J. Power Sources 86 (2000) 111. [10.1016/S0378-7753(99)00407-3]

8. K. Shah, R.S. Besser, J. Power Sources 123 (2008) 172-181. [10.1016/S0378-7753(03)00538-X]

9. M.A. Abdel Rahim, R.M. Abdel Hameed, M.W. Khalif, J. Power Sources 134 (2004) 160. [10.1016/j.jpowsour.2004.02.034]

10. A.K. Shukla, P.A. Christensen, A. Hamnett, M.P. Hogarth, J. Power Sources 55 (1995) 87. [10.1016/0378-7753(94)02150-2]

11. E. Antolini, Mater. Chem. Phys. 78 (2003) 563. [10.1016/S02540584(02)00389-9]

12. E. Antolini, J.R.C. Salgado, L.G.R.A. Santos, G. Garcia, E.A. Ticianelli, E. Pastor, E.R. Gonzalez, J. Appl. Electrochem. $36 \quad$ (2006) 355. [10.1007/s10800-005-9072-0]

13. A.A. AL Shafei, R. Hoyer, L.A. Kibler, D.M. Kolb, J. Electrochem. Soc. 151 (2004) 141. [10.1149/1.1705660]

14. N.S. Alvarez, L.R. Alden, E. Rus, H. Wang, F.J. Disalvo, H.D. Abruna, J. Electroanal. Chem. 626 (2009) 14. [10.1016/j.jelechem.2008.10.028]

15. A.O. Neto, R.W.R.V. Silva, M. Linardi and E.V. Spinace, Int. J. Electrochem. Sci. 4 (2009) 954.

16. B. Beden, F. Kadirgan, C. Lamy and J.M. Leger, J. Electroanal. Chem. 127 (1981) 75. [10.1016/S0022-0728(81)80469-X]

17. K.W. Park, J.H. Choi, B.K. Kubn, S.A. Lee, Y.E. Sung, H.Y. Ha, S.A. Hong. H. Kim, A. Wieckowski, J. Phys. Chem. 106 (2002) 1869. [10.1021/jp013168v] 
18. G. Vertes, G. Horanyi, F. Nagi, Acta. Chim. Acad. Sci. Hung. 68 (1971) 145.

19. M. Fleischmann, K. Korinek, D. Pletcher, J. Electroanal. Chem. 31 (1971) 39. [10.1016/S0022-0728(71)80040-2]

20. Natural phosphate (NP) comes Khouribga Region (Morocco). It is readily available (raw or treated) from CERPHOS, Casablanca.

21. M.A. El Mhammedi, M. Bakasse, A. Chtaini, J. Hazardouz. Mat. 145 (2007) 1. [10.1016/j.jhazmat.2007.02.054]

22. A. Seghiower, J. Chevalet, A. Barhoun, F. Lantelme, J. Electroanal. Chem. 442 (1998) 113. [10.1016/S0022-0728(97)00498-1]

23. J.L. Weininger, M.W. Breiter, J. Electrochem. Soc. 110 (1963) 484. [10.1149/1.2425798]

24. M. Vukovich, J. Appl. Electrochem. 24 (1994) 878. [10.1007/BF00348775]

25. O. Enea, Electrochim. Acta 35 (1990) 375. [10.1016/0013-4686(90)87014-S]

26. S. Berchmans, H. Gomathi, G.P. Rao, J. Electroanal. Chem. 394 (1995) 267. [10.1016/0022-0728(95)04099-A] 